\title{
Pengaturan dan Penegakan Hukum Pengupahan dalam Sistem Hukum Ketenagakerjaan
}

\author{
Zulkarnain Ibrahim \\ Fakultas Hukum Universitas Sriwijaya \\ Jl. Raya Palembang Km. 32 Inderalaya Ogan Ilir Sumatera Selatan \\ zulibrahim007@gmail.com
}

\begin{abstract}
This research discusses the legal arrangement and enforcement of remuneration law in Employment Law (UUK) as an effort to realize the social welfare of workers. The method of this research was juridical empirical which regards law as a fact to observe and value-free. The research finding concludes that, first, UUD NRI (Indonesian Constitution) of 1945 has been weakened by UUK with its practice of labour market system and termination of employment. In addition, UUK has provided an opportunity for businessman to neglect his duty to respect the rights of Labour Union. Second, the enforcement of remuneration law is ineffective. Supevision from the Ministry of Manpower and Transmigration is hampered by the insufficient number of civil servant investigators (PPNS) compared to the number of companies.
\end{abstract}

Key words : Employment law, legal system, living wage

\begin{abstract}
Abstrak
Penelitian ini mengkaji tentang pengaturan dan penegakan hukum pengupahan dalam hukum ketenagakerjaan sebagai upaya mewujudkan kesejahteraan sosial pekerja. Metode penelitian yang digunakan dalam penelitian ini adalah yuridis empirik dengan memandang ilmu hukum sebagai fakta yang diamati dan bebas nilai. Hasil penelitian menyimpulkan, pertama, UUD NRI Tahun 1945 telah dilemahkan oleh UUK dengan praktik labour market system dan PHK. Selain itu, UUK memberi peluang kepada pengusaha untuk mengabaikan kewajibannya menghormati hak asasi SP/SB. Kedua, penegakan hukum pengupahan masih belum efektif. Pengawasan Kemenakertrans terkendala oleh sedikitnya jumlah PPNS dibandingkan dengan jumlah perusahaan.
\end{abstract}

Kata Kunci: Hukum perburuhan, sistem hukum, upah layak 


\section{Pendahuluan}

Penegakan hukum yang lemah, menurut pendapat umum disebabkan oleh budaya hukum yang dinilai tidak kondusif bagi pembangunan sistem hukum. Betulkah lemahnya penegakan hukum dan judicial corruption disebabkan oleh budaya hukum yang terwariskan dari nenek moyang kita? Sebastian Pompe, penulis buku The Indonesian Supreme Court, A Study of Institutional Collapse, menolak mentah-mentah pandangan ini. Pompe mengatakan "nonsense" dan tidak benar sama sekali kalau dikatakan bahwa Indonesia mewarisi budaya korup dari zaman nenek moyang. ${ }^{1}$

Hukum telah menjadi bagian dari keutuhan Sistem Pembangunan Nasional. Untuk dapat membangun hukum secara tepat, diperlukan desain pembangunan hukum yang tepat pula. Salah satu komponen dasar, desain pembangunan yang tepat adalah, pemahaman yang tepat terhadap karakteristik objek pembangunan yang hendak kita bangun. ${ }^{2}$

Pemahaman teoritis terhadap pembangunan hukum, menurut Lawrence Meir Friedman, dalam sistem penegakan hukum yang efektif terdiri dari 3 (tiga) komponen, legal structure, legal substance dan legal culture. Komponen struktur adalah bentuk permanen sebuah lembaga yang bekerja dengan mengikuti proses dan pembatasnya. Sedangkan, komponen substansi yang dimaksud adalah norma-norma ataupun aturan-aturan aktual yang dipergunakan oleh lembaga yang menentukan cara-cara menggambarkan suatu perilaku dan menentukan kemungkinan ke arah mana harus berbuat. Sementara yang dimaksud dengan legal culture adalah elemen sikap dan nilai-nilai sosial yang dimanifestasikan di dalam tingkah laku kongkrit masyarakat. ${ }^{3}$ Kendala budaya yang terjadi di lingkungan berbagai perusahaan yang cenderung hanya memperlakukan kebijakan pengupahan yang berkeadilan prosedural bukan berkeadilan substantif.

1 Moh. Mahfud MD, Membangun Politik. Hukum, Menegakkan Konstitusi, Penerbit PT Raja Grafindo, Bandung, 2011, hlm. 44.

${ }^{2}$ H. Lili Rasjidi, “Pembangunan Sistem Hukum Dalam rangka Pembinaan Hukum Nasional”, dalam: B. Arief Sidharta, Butir-Butir Pemikiran Dalam Hukum, Memperingati 70 Tabun Prof. Dr. B. Arief Sifharta, S.H., Refika Aditama, Bandung, hlm. 133.

${ }^{3}$ Ahmad Mujahidin, Peradilan Satu Atap di Indonesia, Penerbit Refika Aditama, Bandung, 2007, hlm. 182. 
Keadilan prosedural dalam kebijakan Upah Minimum Provinsi (UMP) dari pemerintah adalah sebagai jaringan pengaman (safety net) untuk perusahaan yang lemah dari segi keuntungan, bukan untuk perusahaan yang kuat atau pembayar pajak penghasilan (PPh) yang besar. Oleh karena itu, tidaklah adil perusahaan besar membayar UMP kepada pekerjanya. Sebenarnya menurut pajak penghasilan (PPh), upah dapat ditingkatkan $200 \%$ - $300 \%$, apabila pemerintah dapat: 1) menghentikan pungutan liar seperti pungli terhadap perusahaan di Serang Banten oleh berbagai pihak, termasuk oknum aparat desa, oknum aparat keamanan, dan keamanan lokal yang besarnya Rp. 150.000,- hingga Rp. 500.000,--; 2) menghentikan pungutan-pungutan lain yang mencapai $10 \%$ dari komponen biaya produksi. Pungutan tersebut terlalu besar dibandingkan dengan komponen biaya upah di usaha padat modal sebesar $10 \%$ dan di usaha padat karya 25-30 \%. Pungli ini harus ditekan dan merupakan tugas pemerintah;5 3) menurunkan bunga bank BUMN dan pajak impor untuk bahan baku perusahaan; dan 4) perusahaan sendiri melakukan penghematan pada biaya-biaya rutin.

Sebagai pembanding untuk menentukan upah yang layak di Provinsi Sumatera Selatan pada bulan Januari 2012, bahwa komponen Kebutuhan Hidup Layak (KHL) untuk pekerja lajang dalam sebulan dengan 3.000 kalori per hari, sebesar Rp. 1.602.116,-. Data diambil di Pasar Lemabang, Pasar Cinde dan Pasar 16 Ilir Palembang. ${ }^{6}$

Pemberitaan media massa, terungkap keluhan dan pernyataan dari kalangan pekerja: pertama, pihak buruh dengan terpaksa menerima upah di bawah UMP, yaitu Rp. 650.000,- . Sedangakan uang lembur, transport dan uang makan tidak ada sama sekali; kedua, SPSI Sumsel mempertanyakan penindakan oleh PPNS Disnakertrans sampai ke pengadilan terhadap pelanggaran UMP, meskipun sejumlah laporan pelanggaran yang dilakukan oleh pengusaha dapat diungkapkan; ketiga, Kepala Bidang Pengawasan Disnakertrans, mengakui bahwa: 1) kewenangan mereka tidak sampai melakukan pengawasan langsung, dan 2) minimnya tenaga pengawas; keempat, LBH Palembang juga sama saja tidak

${ }^{4}$ Pungutan liar di perusahaan, Kompas, 30 April 2008.

${ }^{5}$ Ibid.

${ }^{6}$ Disnakertrans Provinsi Sumsel, Daftar Komponen Kebutuban Hidup Layak Provinsi Sumsel, Januari 2012. Sekarang UMP tahun 2012, UMP Kota Palembang Rp. 1.271.000,- ( 7 jam kerja/hari dan/atau 40 jam / minggu). 
berdaya untuk membantu penderitaan pekerja dengan berbagai alasan. ${ }^{7}$ Sedangkan PPNS Kemenakertrans belum bekerja maksimal. ${ }^{8}$

Perbedaan prinsip zaman revolusi industri dengan saat ini, adalah terletak pada ada tidaknya jaminan hukum atau perundang-undangan terhadap pekerja. Namun, perundang-undangan sekarang lemah dalam penegakan hukum, artinya pelanggaran perundang-undangan ketenagakerjaan oleh pengusaha tanpa penyelesaian hukum serta buruh selalu menjadi korban, baik dari pemerasan dan perlakuan yang tidak adil; serta dikekang kebebasan untuk berserikat dan berkumpul.

\section{Rumusan Masalah}

Berdasarkan uraian latar belakang di atas, perlu dianalisis permasalahan hukum tentang bagaimana pengaturan dan penegakan hukum pengupahan dalam sistem hukum ketenagakerjaan, sebagai upaya mewujudkan kesejahteraan sosial pekerja?

\section{Tujuan Penelitian}

Tujuan penelitian adalah untuk mengetahui pengaturan dan penegakan hukum pengupahan dalam sistem hukum ketenagakerjaan, sebagai upaya mewujudkan kesejahteraan sosial pekerja.

\section{Metode Penelitian}

Untuk penelitian ilmu hukum normatif yang dikaji adalah bahan hukum yang berisi aturan-aturan yang bersifat normatif: pertama, bahan hukum primer,

7 Sekretaris SPSI Sumsel, Pertanyakan Kinerja Pengawas Disnakertrans, Sumatera Ekspres, 11 Februari 2011, hlm 11.

8 Penyidik Pegawai Negeri sipil (PPNS) di lingkungan Disnakertrans Sumsel belum efektif melaksanakan tugas pengawasan dengan alasan klasik, misalnya minimnya tenaga pengawas atau PPNS. Namun, menurut pihak SPSI meskipun sejumlah laporan pelanggaran UMP oleh pengusaha terungkap tapi kasus mana yang sudah sampai ke meja hijau. Kalau dalih kekurangan tenaga pengawas, bukan menjadi alasan untuk lalai menegakkan perundang-undangan ketenagakerjaan; Lihat: Direktur LBH Palembang, Buka Posko Pengaduan, Sumatera Ekspres, 11 Februari 2011, hlm.11. 
khususnya peraturan peraturan perundang-undangan; Kedua, bahan hukum sekunder, yang terdiri dari buku, Jurnal, laporan penelitian, artikel ilmiah hukum dan sosial, serta bahan seminar, lokakarya, dan sebagainya. Bahan-bahan hukum yang diperoleh akan dianalisis dengan cara deskriptif kualitatif, khusus dalam penerapan aturan hukum di bidang pengupahan.

\section{Hasil Penelitian dan Pembahasan}

\section{Kendala dalam Tataran Substansi Hukum}

\section{Inkonsistensi dalam Peraturan Perusahaan}

Inkonsistensi adalah tidak sesuainya antara substansi hukum dari UndangUndang No. 13 Tahun 2003 tentang Ketenagakerjaan (UUK), yang mengatur suatu hal yang berkaitan atau ketidaksinkronan. Dalam Black Law Dictionary, dikatakan "locking consistency, not compatible with another fact or claim". Dalam RPJMN 2004-2009 disebutkan bahwa masalah politik hukum pada umumnya menyangkut masalah substansi hukum yang ditandai oleh adanya inkonsistensi peraturan perundang-undangan. ${ }^{9}$

Hukum substantif sealur dengan pemikiran Satjipto Rahardjo tentang hukum progresif, sebagai berikut: pertama, hukum itu adalah untuk manusia, bukan sebaliknya. Oleh karena itu, kendati hukum itu dimulai dari teks undangundang, tetapi selanjutnya pekerjaan berhukum itu diambil oleh manusia dan membuat keputusan; kedua, menjalankan hukum itu adalah menciptakan keadilan dalam masyarakat; ketiga, hakim bukanlah legislator, karena tugasnya adalah ajudikasi (ajudication) atau memeriksa atau mengadili. ${ }^{10}$

Untuk mencapai Hukum Ketenagakerjaan responsif salah satunya menghilangkan inkonsistensi dalam hukum ketenagakerjaan itu sendiri. Alasan inkonsistensi tersebut dilatarbelakangi: 1) UUK telah disusun dengan melanggar prinsip-prinsip dan prosedural penyusunan dan pembuatan sebuah UndangUndang yang patut, yang terlihat dari fakta tidak adanya "naskah akademis"

9 Agusmidah, 2011, Dilematika Hukum Ketenagakerjaan, Tinjauan Politik Hukum. Penerbit PT. Sofmedia, Medan, hlm. 23-24.

${ }^{10}$ Satjipto Rahardjo, Negara Hukum yang Membahagiakan Rakyatnya, Genta Publishing, Yogyakarta, 2009, hlm. 23 . 
yang memberi dasar pertimbangan ilmiah perlunya undang-undang a quo; dan 2) UUK sebagai satu dari "Paket 3 UU Perburuhan", dibuat semata-mata karena tekanan kepentingan modal asing daripada kebutuhan nyata pekerja Indonesia. ${ }^{11}$

Alasan pengujian materil dalam perkara ini didasarkan pada dalil yang dikemukakan oleh pemohon bahwa UUK bertentangan dengan UU 1945, khususnya Pasal 27 ayat (1), dan Pasal 28, secara substansial lebih buruk dari Undang-Undang sebelumnya. Inti pokok UUK, pertama, adalah membuat mekanisme pasar bekerja bebas, di mana buruh sebagai komoditas di pasar tenaga kerja yang dipakai ketika perlu dan dibuang jika tidak menguntungkan lagi. Perlindungan hukum perburuhan semakin dikurangi dan buruh dibiarkan sendirian menghadapi ganasnya kekuatan pasar dan modal, hal mana bertentangan dengan Pasal 27 ayat (2) UUD 1945. Kedua, UUK dalam beberapa pasalnya memasung hak fundamental pekerja dan SP/SB, bertentangan dengan Pasal 28 UUD 1945 yang menjamin kemerdekaan berserikat dan berkumpul, mengeluarkan pikiran dengan lisan dan tulisan. Pasal 119 UUK yang mensyaratkan bahwa untuk melakukan perundingan pembuatan PKB harus dapat membuktikan bahwa SP/SB tersebut memiliki jumlah anggota lebih dari $50 \%$ di perusahaan bersangkutan, kalau tidak, harus mendapat dukungan lebih dari 50\% dari jumlah seluruh pekerja di perusahaan tersebut. Hal ini diartikan bahwa Pasal 119 Undang-Undang a quo memberi peluang kepada pengusaha untuk mengabaikan kewajibannya menghormati hak asasi SP/SB untuk berserikat dan berkumpul di lingkungan perusahaan. ${ }^{12}$

Inkonsistensi yang menimbulkan kerancuan tersebut, karena dibangun dan masih berpijak pada suatu kultur politik dari masa lalu dengan menempatkan hubungan kerja diperatas antara pengusaha dengan pekerja. Hukum represif pada masa penjajahan Belanda, dan hukum otonom pada masa Orde Lama dan Orde Baru; hendaknya menjadi hukum responsif pada masa kini.

11 Agusmidah, Op.Cit., hlm. 94.

12 Agusmidah, Ibid., hlm 94-100. 


\section{Ketidakpastian Hukum}

Tujuan hukum adalah keadilan, kemanfaatan dan kepastian hukum untuk mencapai kesejahteraan masyarakat. Menurut Dominikus Rato, agar tujuan hukum tercapai, maka diperlukan kaedah hukum yang tegas, jelas, tidak berdwiarti, diterapkan secara konsisten, dan dipertahankan secara pasti yang disebut kepastian hukum. Oleh karena itu, beberapa persyaratan harus dipenuhi, yaitu: 1) hukum itu tidak boleh berlaku surut; 2) keputusan hukum tidak boleh simpang siur; 3) keputusan hukum tidak boleh pandang bulu antar pilih kasih;dan 4) kondisi sosial politik harus stabil dan normal. ${ }^{13}$

Nilai-nilai kepastian hukum dalam hukum ketenagakerjaan, harus satu kesatuan dengan nilai keadilan dan kemanfaatan. Kepastian hukum dalam peraturan-peraturan akan dipatuhi oleh pekerja dan pengusaha bila bermanfaat dan memberi keadilan bagi mereka. Peranan pejabat Kemenakertrans memberi andil yang besar untuk tercapainya tujuan hukum yang mensejahterakan pekerja dan pengusaha. Pihak pekerja hendaknya meningkatkan keahliannya dengan bantuan pemerintah dan pengusaha agar bekerja secara profesional, sehingga akan menguntungkan dirinya dan pengusaha. Sedangkan pihak pengusaha, juga tidak hanya berhasil meningkatkan kemajuan dan keuntungan perusahaannya tetapi juga dapat meningkat pendapatan pekerjanya.

Inkonsistensi dan ketidakpastian peraturan perundang-undangan di bidang pengupahan, menjadi penyebab dari konflik antara pekerja dengan pengusaha dan pemerintah serta antara pengusaha dengan pemerintah. Persoalan, adalah ketidaksamaan pendapat/pandangan tentang upah. Upah sudah sejak lama menjadi sorotan berbagai kalangan yang terlibat dalam hubungan industrial karena posisi upah sangat strategis. ${ }^{14}$

Sikap pengusaha dipengaruhi oleh kesulitan keuangan karena hasil produksinya kalah bersaing baik di pasar lokal atau luar negeri. Hal ini terjadi di perusahaan tekstil yang mempekerjakan 600-an orang pekerja. Para pekerja

13 Dominikus Rato, Filsafat Hukum., Mencari, Menemukan, dan Memahami Hukum, Penerbit LaksBang Justitia Surabaya, Surabaya, 2011, hlm. 150-151.

14 Cosmas Batubara, "Menyegarkan Kembali UMP dan Upah yang Adil”, Makalah pada Seminar Kemenakertrans, Strategi Pengupaban Cerdas dalam Rangka Keadilan dan Produktivitas, Hotel Ciputra, Jakarta, 15-16 Maret 2012, hlm. 2. 
sangat mengerti kesulitan keuangan perusahaan, bersedia berhenti bekerja sebagai pekerja tetap dengan hak-hak mendapat uang pesangon, uang penghargaan masa kerja dan ganti rugi. Kemudian para pekerja tetap bekerja sebagai Pekerja waktu tertentu (melalui perjanjian kerja waktu tertentu atau PKWTT) dengan menerima UMK Kabupaten Bogor sebesar Rp. 2.050.000,- , tanpa ada hak-hak lain. Perusahaan hanya memberi waktu kerja 8 jam setiap hari tanpa adanya waktu kerja lembur, dikarenakan tidak mampu membayar upah lembur. Namun, para pekerja tetap mendapat Jamsostek dan THR. ${ }^{15}$

Berbagai faktor penyebab produksi perusahaan kalah bersaing di pasar dalam negeri dan luar negeri, yaitu: 1) perusahaan yang besar karena padat karya; 2) bahan baku impor yang besar; 3) perusahaan tidak efisien; dan 4) budaya perusahaan tidak disiplin. Di samping itu penyebab lainnya adalah:1) tingkat pendidikan pekerja yang didominasi oleh pendidikan rendah, pangsa dan pertumbuhan; 2) skill yang rendah atau tidak memiliki keterampilan; dan 3) perbandingan produktivitas dengan negara lain masih rendah.

Klasifikasi terhadap pekerja terlantar (penganggur) menurut penelitian Kletzer 1998, 2001 dan 2004 dengan sampel industri yang terkena kompetisi atau persaingan internasional. Pendekatan ini didasarkan pada tiga tempat penting. Pertama, mengidentifikasi industri yang paling terpengaruh oleh peningkatan kompetisi internasional. Kedua, bahwa meningkatnya kompetisi asing merupakan penyebab penting dari kehilangan pekerjaan. Ketiga, bahwa pekerja terlantar atau menjadi penganggur, sebagai bagian dari industri yang kalah menghadapi meningkatnya persaingan internasional. ${ }^{16}$

Sedangkan di Indonesia, pengangguran ${ }^{17}$ jumlahnya terus menurun dalam periode 2011-2013. Namun, ada istilah pekerja tidak penuh tahun 2013 (35, 71 juta), setengah penganggur (13, 56 juta), dan bekerja paruh waktu (22,15 juta). Jika

15 Wawancara dengan Eddi Emik (52 tahun), Saleh (52 tahun), Yani (48 tahun), dan Kasdu (45 tahun) dengan masa kerja mereka antara 15 tahun s.d. 21 tahun. Kesemuanya adalah pekerja pada PT. Ever Shinetex, Cibinong-Bogor. Wawancara tanggal 19 Agustus 2013 di Cibinong Kabupaten Bogor.

${ }^{16}$ Paulo Bastos and Joana Silva, “The Wage and Unemployment Impacts of Trade Adjustment” Dalam: David Greenaway cs, Globalisation and Labour Market Adjustment, New York: Palgrave Macmillan, 2008, hlm 41.

${ }^{17}$ Di Jepang, mereka yang diberhentikan tidak dianggap sebagai penganggur, tetap dianggap semacam cuti sementara. Selama resesi, perusahaan yang memberhentikan mereka, tetap mencantumkan dalam daftar gaji, dan diberi gaji tidak penuh. Sebagian besar pekerja tersebut percaya bahwa mereka akan kembali dipekerjakan. Lihat: Toshihiko Yamagami, "Utilization of labor resources in Japan and the United States", Monthly Labor Review April 2002, hlm. 26 dan 29. 
ketiga jenis pengangguran ini diberi pekerjaan oleh pemerintah dengan menciptakan lapangan pekerjaan, maka akan menghasilkan devisa bagi negara, meningkatkan penerimaan pajak, mengurangi kesenjangan sosial dan menurunkan angka kejahatan. Para pengangguran tersebut, terdiri dari tenaga kerja terampil dan tidak terampil.

Untuk mengatasi pengangguran, Takeo Kikkawa meneliti tentang penciptaan lapangan kerja. Dalam mengejar tujuan ini, fakta bahwa divergensi regional melebar selama proses Jepang mengalami pemulihan ekonomi yang dimulai pada tahun 2002. Kikkawa menganalisis kenaikan dan penurunan jumlah pekerja, dari industri di enam prefektur dengan keadaan yang sebelumnya relatif menguntungkan tenaga kerja di 1999-2004 (Okinawa Prefektur, Tokyo Metropolis, Nara Prefecture, Prefektur Chiba, Shiga Prefektur, dan Kumamoto Prefecture). Kikkawa mengetahui keberhasilan "inovasi dalam industri tersier (bisnis perluasan restoran dan industri akomodasi, keberhasilan relatif perdagangan grosir dan eceran)". Industri ini telah meningkatkan penciptaan lapangan pekerjaan dan pengurangan jumlah penganggur. ${ }^{18}$

Menurut Johnson W. Makoba, para pekerja yang terpinggirkan cenderung rendah keterampilan dan bayarannya, tanpa keamanan kerja. Pekerjaan dilakukan oleh sebagian besar perempuan muda yang dilakukan di bawah kemampuan mereka yang lebih dekat dengan seorang budak dari pekerjaan yang sah. Perusahaan di negara kapitalis cenderung menghilangkan pekerja yang kurang terampil dan memberi pekerjaan kasar saja. ${ }^{19}$

Pemikiran kapitalis di atas, menimbulkan kesadaran baru, ditandai dengan munculnya teori sosial yang ingin mengimbangi gagasan di balik doktrin laissezfaire. M. G. Rood berpendapat bahwa undang-undang perlindungan buruh merupakan contoh yang memperlihatkan ciri utama hukum sosial yang didasarkan pada teori ketidakseimbangan kompensasi. Teori ini bertitik tolak pada pemikiran bahwa antara pemberi kerja dan penerima kerja ada ketidaksamaan kedudukan secara sosial-ekonomis. Penerima kerja ini dipandang sebagai

18 Takeo Kikkawa, "Community Based Renaissance and Job Creation in Japan", Hitotsubashi University, Japan Labor Review Vol. 5, no. 1, Winter, 2008, hlm 55.

19 Johnson W. Makoba, "Globalization and Marginalization of Labor: Focus on Sub-Saharan Africa" Dalam: Berch Berberoglu, Globalization In The 21 st Century: Labor, Capitral, and State on a World Scale, Palgrave Macmillan, New York, 2010, hlm . 97. 
jawaban yang tepat terhadap rasa keadilan umum, bergantung pada pemberi kerja, maka hukum perburuhan memberi hak lebih banyak kepada pihak yang lemah daripada pihak yang kuat. Hukum bertindak "tidak sama" kepada masingmasing pihak dengan maksud agar terjadi suatu keseimbangan yang sesuai. ${ }^{20}$

Teori ketidakseimbangan kompensasi, keseimbangan pengusaha memberikan upah yang layak dengan diimbangi oleh produktivitas pekerja Indonesia yang tinggi. Namun kenyataannya data dari Aviliani tentang tenaga kerja yang tidak terampil dapat di lihat pada tabel di bawah ini.

Tabel 1

Skill yang rendah

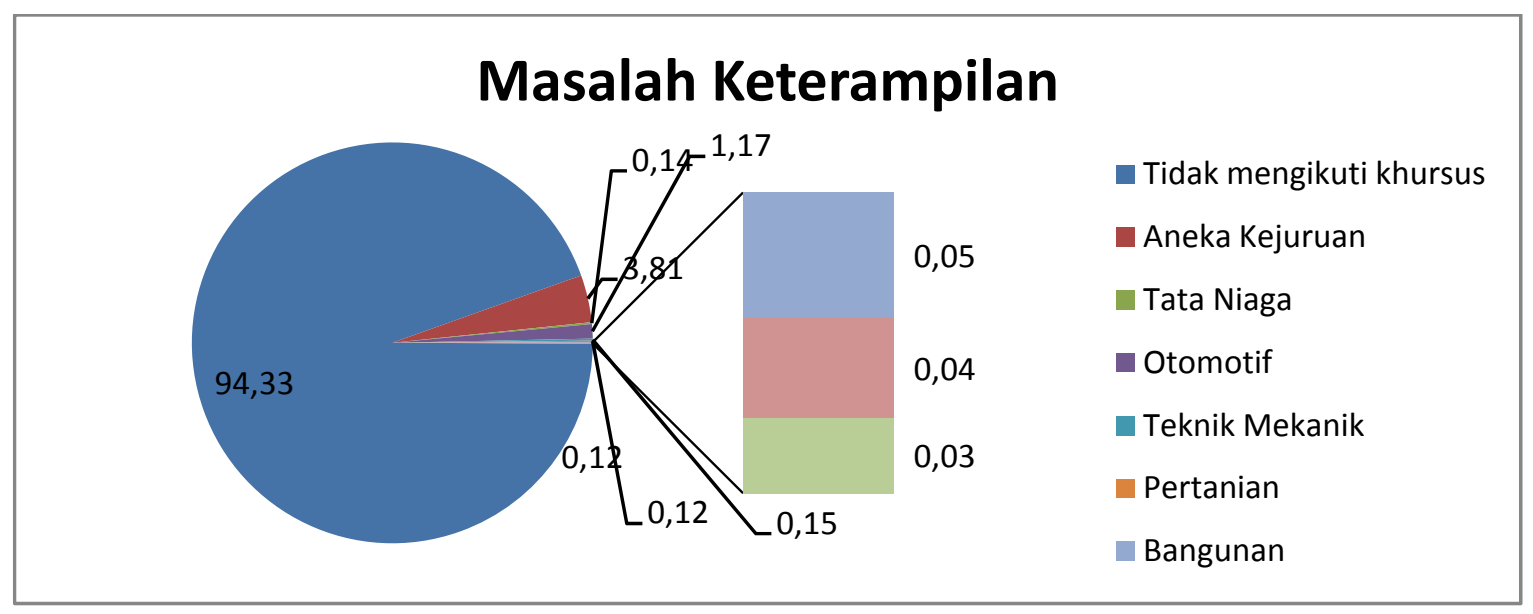

Sumber: Aviliani, Biaya Tenaga Kerja di Indonesia, disampaikan pada Forum Konsolidasi Dewan Pengupahan se Indonesia, Jakarta, tanggal 3-5 September 2013.

Penjelasan tentang tenaga kerja yang tidak terampil di atas, datanya 94, 33 persen dan yang terampil 5, 67 persen. Penyebabnya, tenaga kerja: 1) tinggal di pedesaan, mereka tidak terjangkau oleh lembaga/kursus keterampilan; 2) kursus keterampilan biayanya mahal; 3) Balai Latihan Kerja ada di Ibu Kota Provinsi.

Rendahnya produktivitas pekerja Indonesia berdasarkan survey Organisasi Produktivitas Asia (APO), pada produksi Sepatu (dalam satuan waktu yang sama, alat yang sama dan penyediaan bahan baku yang sama) sebagai berikut : a) pekerja Jepang 6,6 ; b) pekerja Korea 5,2; c) pekerja China 4,6; d)

${ }^{20}$ Tri Hermintasdi, " Efektivitas Pelaksanaan Hukum di Bidang Hukum Perburuhan Berdasarkan UU. No. 13 tahun 2003 Tentang Ketenagakerjaan”, Artikel dalam Majalah Hukum Varia Peradilan, No. 281, April 2009, hlm 60 . 
pekerja Vietnam 3, 7; dan e) pekerja Indonesia 3,3.21 Berdasarkan data ini jika dibandingkan dengan produktivitas pekerja Jepang, maka produktivitas pekerja Indonesia hanya 50 \% dari Jepang. Berbagai alasan yang menjadi lemahnya produktivitas pekerja Indonesia, di samping rendahnya upah juga kendala infrastruktur dan biaya sogok perusahaan penyebab inefisiensi. Untuk itu dapat dilihat pada tabel di bawah ini.

Tabel 2

Kendala Infrastruktur

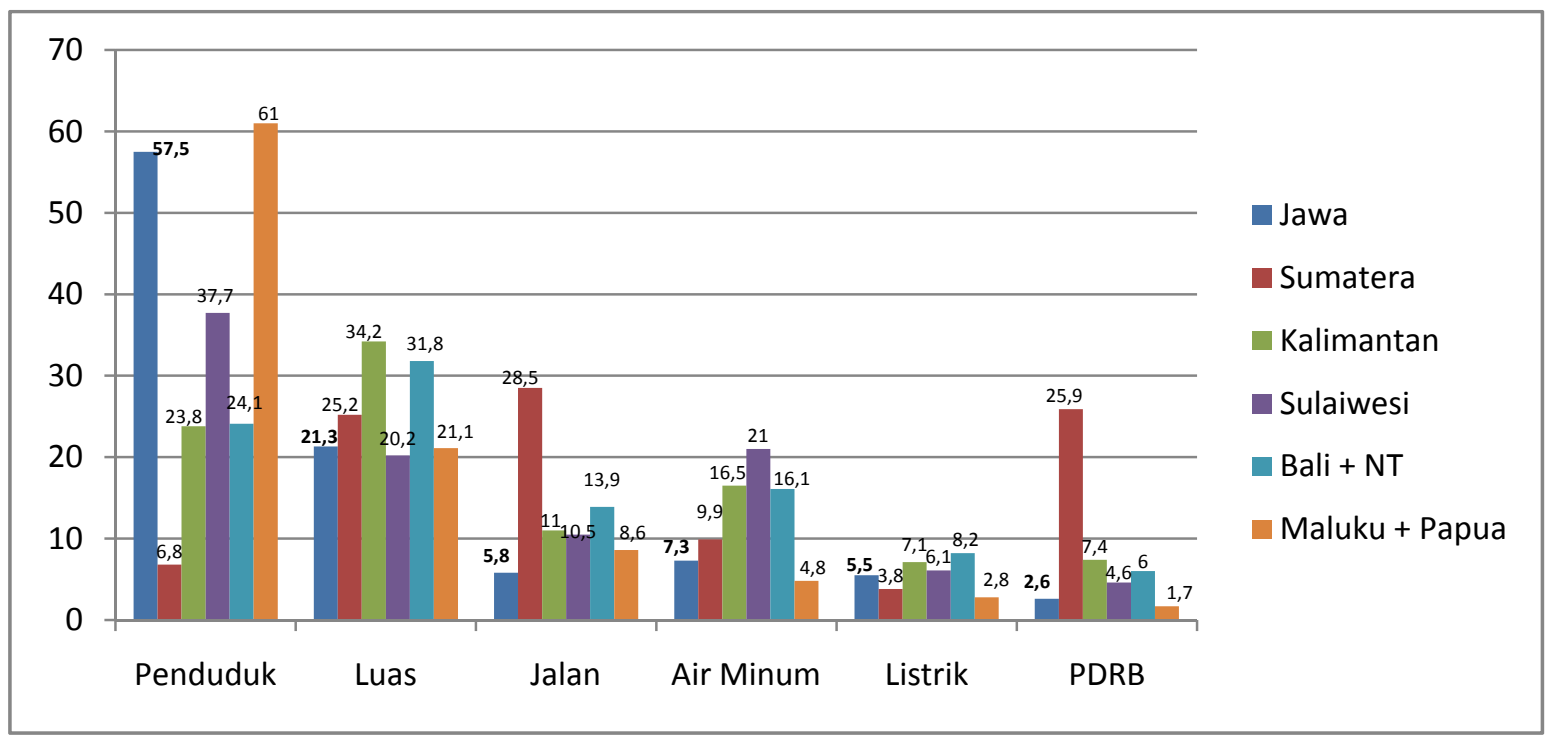

Penjabaran Kondisi Jalan di Indonesia:

\begin{tabular}{|l|l|l|l|l|l|l|}
\hline & Baik & Sedang & Mantap & $\begin{array}{c}\text { Rusak } \\
\text { Ringan }\end{array}$ & $\begin{array}{c}\text { Rusak } \\
\text { Berat }\end{array}$ & $\begin{array}{c}\text { Tidak } \\
\text { Mantap }\end{array}$ \\
\hline Sumatera & 20 & 17,2 & 37,3 & 2,6 & 17,6 & 5,3 \\
\hline Jawa & 20,1 & 16,2 & 36,3 & 2,2 & 0,5 & 24,7 \\
\hline Kalimantan & 2,4 & 80 & 5,3 & 0,8 & 9,8 & 1,7 \\
\hline Sulawesi & 5,7 & 61,4 & 8,6 & 20,9 & 1,3 & 2,1 \\
\hline Maluku dan Papua & 0,6 & 1,5 & 66,3 & 2,5 & 24 & 5,1 \\
\hline \multicolumn{7}{|l|}{ Sumber : Diolah dari PU, 2010 } \\
\hline
\end{tabular}

Sumber: Aviliani, Biaya Tenaga Kerja di Indonesia, disampaikan pada Forum Konsolidasi Dewan Pengupahan se Indonesia, Jakarta, tanggal 3-5 September 2013.

Ternyata data infrastruktur Indonesia, antar provinsi sangat jauh berbeda. Jalan rusak berat di Pulau Jawa sangat kecil (0,5\%), di Sumatera sangat besar $(17,6 \%)$. Ketimpangan ini disebabkan kebijakan pembangunan yang tidak baik

${ }^{21}$ Syukur Sarto, "Upah untuk Menjaga Produktivitas Kerja”, Makalah pada Seminar Kemenakertrans, Hotel Ciputra, Jakarta, tanggal 15-16 Maret 2012, hlm. 6. 
dan merata dari Pemerintah Pusat dan Pemerintah Daerah yang salah satu penyebabnya, adalah mengguritanya Korupsi, kolusi dan nepotisme.

Aviliani menunjukkan besarnya inefisiensi birokrasi, infrastruktur dan korupsi dalam tabel berikut ini.

Tabel 3

Biaya Sogok Perusahaan Penyebab Inefisiensi

\begin{tabular}{|c|c|c|c|}
\hline Periode & Rank & $\begin{array}{c}\text { Total } \\
\text { Negara }\end{array}$ & Tiga Masalah Utama \\
\hline GCI 2009-2010 & 54 & 133 & $\begin{array}{l}\text { 1. Inefisiensi Birokrasi Pemerintah }(20,2 \%) \\
\text { 2. Ketidatersediaan Infratruktur }(14,8 \%) \\
\text { 3. Ketidakstabilan Kebijakan }(9 \%)\end{array}$ \\
\hline GCI 2009-2011 & 44 & 139 & $\begin{array}{l}\text { 1. Inefisiensi Birokrasi Pemerintah }(16,2 \%) \\
\text { 2. Korupsi }(16 \%) \\
\text { 3. Ketidatersediaan Infratruktur }(8,4 \%)\end{array}$ \\
\hline GCI 2009-2012 & 46 & 142 & $\begin{array}{l}\text { 1. Korupsi }(15,4 \%) \\
\text { 2. Inefisiensi Birokrasi Pemerintah }(14,3 \%) \\
\text { 3. Ketidatersediaan Infratruktur }(9,5 \%)\end{array}$ \\
\hline GCI 2009-2013 & 50 & 144 & $\begin{array}{l}\text { 1. Inefisiensi Birokrasi Pemerintah }(15,4 \%) \\
\text { 2. Korupsi }(14,2 \%) \\
\text { 3. Ketidatersediaan Infratruktur }(8,3 \%)\end{array}$ \\
\hline
\end{tabular}

Sumber: Aviliani, Biaya Tenaga Kerja di Indonesia, disampaikan pada Forum Konsolidasi Dewan Pengupahan se Indonesia, Jakarta, tanggal 3-5 September 2013.

Data yang dikemukakan Eviliani di atas, ${ }^{22}$ menjadi alasan kenapa produksi perusahaan kalah bersaing di pasar dalam negeri dan luar negeri. Kemudian tahun 2012-2013, inefisiensi Birokrasi Pemerintahan 15,4 \%, Korupsi 14,2 \%, dan ketidaksediaan infrastruktur $8,3 \%$.

\section{Kendala dalam Kebijakan Penentuan Upah Minimum}

Kebijakan Penentuan UM, harus dilihat dari efektivitasnya. UM hanya efektif pada negara yang sistem hukumnya sudah baik, karena di negara yang sistem hukumnya belum baik, upah minimum tidak dapat efektif sesuai

22 Aviliani, "Biaya Tenaga Kerja di Indonesia”, Makalah pada Forum Konsolidasi Dewan Pengupahan se Indonesia, Jakarta, tanggal 3-5 September 2013. 
filosofinya. ${ }^{23}$ Untuk lebih jelas perkembangan UMP menurut Aviliani dapat dilihat pada tabel di bawah ini. ${ }^{24}$

Tabel 4

Perkembangan UMP Nominal dan Pertumbuhan UMP 2005-2013

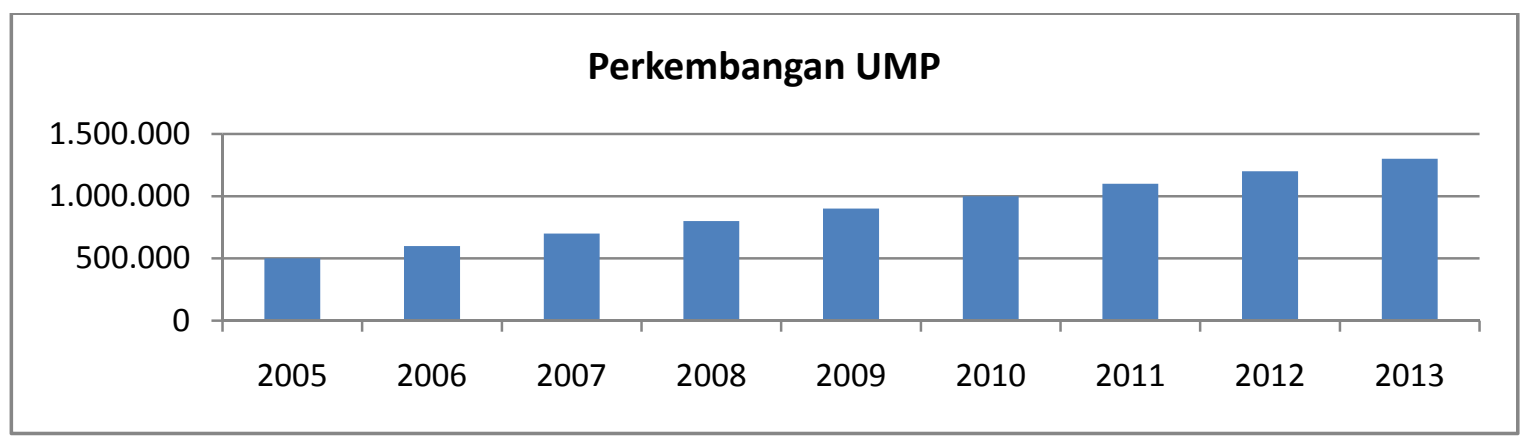

Sumber: Aviliani, Biaya Tenaga Kerja di Indonesia, disampaikan pada Forum Konsolidasi Dewan Pengupahan se Indonesia, Jakarta, tanggal 4 September 2013.

Kenyataan tingkat upah Indonesia masih di bawah Malaysia, Filipina dan China; dikarenakan kondisi dan kendala dalam Kebijakan Penentuan UMP, pertama, pada umumnya: a) kesepakatan dalam survei memilih pasar dan harga barang dan jasa yang sesuai serta menetapkan nilai KHL; b) kesepakatan dalam tim pengupahan menetapkan upah dimaksud; c) tantangan dari pekerja atau SP/SB; dengan demonstrasi dan pemogokan; d) tidak semua perusahaan mematuhi UMP;dan e) perusahaan yang memberlakukan UMP bagi pekerja yang berpendidikan SLTA dan atau pengalaman kerja lebih dari 2 tahun. ${ }^{25}$

Katsudo Tomoaki (Japan International Cooperation Agency, Labor Policy Advisor) pada Depnakertrans, mendukung peningkatan UM dengan menyatakan bahwa peningkatan UM di Jepang untuk memperbaiki dan meningkatkan kualitas kehidupan pekerja serta menjaga keseimbangan persaingan dunia usaha. ${ }^{26}$ Yoshihiko Ono pada Labor and Social Security Attorney Jepang menyatakan hal yang sama bahwa Undang-Undang tentang Upah Minimum di Jepang bertujuan : a) meningkatkan kondisi kerja untuk pekerja yang

23 I Wayan Gde Wiryawan, " Efektifitas Upah Minimum dalam Sistem Penetapan Upah di Indonesia", Makalah pada Forum Konsolidasi Dewan Pengupahan se Indonesia, Jakarta, tanggal 3-5 September 2013.

24 Aviliani, “Biaya Tenaga Kerja di Indonesia”, Makalah pada Forum Konsolidasi Dewan Pengupahan se Indonesia, Hotel Ciputra, Jakarta, tanggal 3-5 September 2013

25 Payaman Simanjuntak, wawancara pada Forum Konsolidasi Dewan Pengupahan se Indonesia, Hotel Ciputra, Jakarta, tanggal 3-5 September 2013.

26 Wawancara dengan Katsudo Tomoaki, Penasihat Perburuhan Jepang yang berkerjasama dengan Kemenakertrans, Jakarta, 4 September 2013. 
berpenghasilan rendah; b) menyeimbangkan kondisi hidup pekerja; c) meningkatkan kualitas angkatan kerja; d) memberikan keamanan persaingan yang sehat antar para pebisnis; dan e) mempromosikan keselarasan pengembangan pembangunan ekonomi nasional. ${ }^{27}$

Agar perusahaan yang mampu membayar upah di atas UMP, SP/SB diberdayakan agar mampu berunding untuk menetapkan upah berdasarkan struktur dan skala upah dengan memperhatikan analisa dan evaluasi jabatan. Struktur dan skala upah yang dapat dilaksanakan di internal perusahaan akan melahirkan keadilan eksternal yang artinya mempunyai daya saing di pasar kerja. Upah minimum, misalnya Rp. 1.500.000,- setelah melalui struktur dan skala upah, upahnya menjadi di atas Rp. 1.750.000,-. Kenaikan upah secara diam-diam di intern perusahaan antara perusahaan dan SP/SB, lebih baik dibandingkan dengan kenaikan melalui cara diumumkan oleh Gubernur tanpa memperhatikan saran-saran Dewan Pengupahan atau pertimbangan politik (populis) yang akan menyebabkan: 1) kenaikkan harga bahan pokok masyarakat, 2) kecenderungan perusahaan mengajukan penangguhan kenaikan upah tersebut. Oleh karena itu akan lebih baik upah naik dari Rp. 1.600.000,-- menjadi Rp. 1.800.000,-; dari pada Rp. 2.200.000,-- tetapi perusahaan mengajukan penangguhan upah tersebut; dan 3) perusahaan menolak kenaikan upah dengan mengajukan gugatan melalui PTUN. ${ }^{28}$

Di samping itu, kendala umum ketika akan ditentukan besaran upah minimum: 1) ada keengganan pengusaha untuk menaikkan upah minimum karena kondisi keuangan perusahaannya yang tidak sehat; 2) pihak pekerja dan SP/SB yang gagal musyawarah untuk menaikkan upah minimum, langsung melakukan unjuk rasa menuntut kenaikan upah minimum.

\section{Kendala dalam Kebijakan Penentuan Upah Layak}

Inkonsistensi dalam substansi hukum, salah satunya adalah tidak adanya kepastian hukum. Asas kepastian hukum, pertama, adalah jaminan terwujudnya

${ }^{27}$ Yoshihiko Ono, "Upah Minimum Jepang", Makalah pada Forum Konsolidasi Dewan Pengupahan se Indonesia, Jakarta, tanggal 3-5 September 2013

28 Ibid., Lihat: pertama, UUK Pasal 92, (1) Pengusaha menyusun struktur dan skala upah dengan memperhatikan golongan, jabatan, masa kerja, pendidikan, dan kompetensi, (2) Pengusaha melakukan peninjauan upah secara berkala dengan memperhatikan kemampuan perusahaan dan produktivitas, (3) Ketentuan mengenai struktur dan skala upah sebagaimana dimaksud dalam ayat (1) diatur dengan Keputusan Menteri; 
hak dan kewajiban penyelenggaraan pelayanan; kedua, asas dalam negara hukum yang mengutamakan landasan peraturan perundang-undangan, kepatutan, dan keadilan dalam setiap kebijakan penyelenggara negara; sebagaimana Penjelasan Pasal 3 Undang-Undang Nomor 28 Tahun 1999 tentang Penyelenggara Negara yang Bersih dan Bebas dari Korupsi, Kolusi, dan Nepotisme. ${ }^{29}$

Komponen Kebutuhan Hidup Layak (KHL) dirumuskan dalam Peraturan Menakertrans No. 13 Tahun 2012 tentang Komponen dan Pelaksanaan Tahapan Pencapaian Kebutuhan Hidup Layak. Dalam Peraturan Menakertrans dimaksud, kebutuhan hidup layak (KHL) dihitung berdasarkan kebutuhan hidup pekerja dalam memenuhi kebutuhan mendasar yang meliputi kebutuhan akan pangan dan minuman 3000 kkal per hari, ditambah komponen sandang, perumahan, pendidikan, transportasi, rekreasi dan tabungan. Kebutuhan tersebut mencakup 7 komponen yang terdiri dari 60 jenis barang dan jasa. ${ }^{30}$

Sementara buruh memiliki sendiri versi mengenai komponen KHL. Ada yang mengajukan konsep bahwa untuk buruh lajang terdapat 86 komponen KHL sementara untuk mereka yang sudah berkeluarga maka terdapat 122 komponen. Banyak komponen KHL yang tidak dipertimbangkan dalam Permenakertrans No 13 Tahun 2012 seperti sumbangan kemasyarakatan dan biaya pendidikan untuk anak buruh. Demikian juga kebutuhan buruh untuk bisa memiliki rumah walaupun tipe sederhana. Sementara itu penelitian dari Lembaga Akatiga menyimpulkan bahwa agar buruh dapat hidup layak maka setidaknya ada 163 komponen KHL yang harus diperhitungkan. ${ }^{31}$

Syukur Sarto melihat kenaikan UMP DKI Jakarta sudah di atas KHL, sebab KHL 2013 sebesar Rp. 1.987.212. Sedangkan UMP DKI Jakarta tahun 2013 adalah Rp. 2.216.234,-, atau UMP DKI 111,5 \% dari KHL , atau 144 \% dari UMP DKI 2012. Munculnya UMP DKI Jakarta 2013, tidak lepas dari peranan KSPSI menemui dan meyakinkan Wagub DKI Jakarta dengan menawarkan kenaikan UMP

29 R.M. Surahman, "Ombudsman Indonesia, Pelayanan Publik dan Asas-asas Hukum bagi Pemerintahan yang Baik" Dalam: Elly Erawaty dkk, Beberapa Pemikiran Tentang Pembangunan Sistem Hukum Nasional Indonesia, Penerbit Citra Aditya Bakti, Bandung, 2011, hlm. 387- 397.

30 Wawancara dengan Payaman Simanjuntak, Pakar Ekonomi SDM dan Mantan Pejabat Eselon I Depnakertrans, Jakarta, tanggal 4 September 2013.

31 Ibid. 
berdasarkan perhitungan kenaikan 0,5 \% setiap bulan dari Januari 2012 s.d. Juli 2013-.32

Apa yang dikatakan Syukur Sarto, adalah benar untuk KHL bagi pekerja lajang, namun untuk pekerja yang telah berkeluarga dengan isteri dan 2 orang anak, UMP DKI Jakarta tidak dapat dikatakan sebagai upah untuk hidup layak (KHL). Maka wajar saja pada 4 September, terjadi demontrasi besar-besaran di Depan Istana Merdeka menuntut UMP di Provinsi DKI sebesar Rp. 3.700.000,untuk UMP 2014. UMP sebesar ini wajar kalau masuk perhitungan KHL untuk pekerja dan 3 orang anggota keluarganya.

\section{Kendala dalam Tataran Struktur Hukum (Lembaga Pengawas)}

Pemerintah melalui pengawas perburuhan berdasarkan UU No. 23 Tahun 1948 jo. UU. No. 3 Tahun 1951 tentang Pengawasan Perburuhan diberikan wewenang: 1) mengawasi berlakunya undang-undang dan peraturan perburuhan pada khususnya; 2) mengumpulkan bahan-bahan keterangan tentang soal-soal hubungan kerja dan keadaan perburuhan dalam arti yang seluas-luasnya guna membuat undang-ndang dan peraturan perburuhan lainnya; 3) menjalankan pekerjaan lainnya yang sesuai dengan peraturan perundang-undangan. ${ }^{33}$

Aparat yang profesional tersebut, dalam penegakan hukum, berarti ia patuh pada hukum dan menegakkannya untuk orang lain. Menurut Hikmahanto Juwana, patuh pada hukum bukanlah tataran yang tertinggi. Tataran tertinggi adalah bila setiap individu dalam masyarakat bersikap di bawah alam sadarnya sesuai dengan tujuan hukum. Di sini hukum terinternalisasi dalam perilaku individu. ${ }^{34}$ Tentang PPNS Kemenakertrans, Syukur Sarto sebagai Ketua KSBSI menilai bahwa dulunya gaji PPNS kecil, maka wajar kalau kinerjanya rendah. Sekarang seharusnya kinerja PPNS ini sudah meningkat, karena gaji PNS sudah besar ditambah lagi dengan tunjangan fungsional dari PPNS tersebut. ${ }^{35}$

\footnotetext{
32 Syukur Sarto, Op. Cit., hlm. 6.

33 Lalu Husni, Pengantar Hukum Ketenagakerjaan Indonesia, Edisi Revisi, PT. RajaGrafindo Persada, Jakarta, 2005, hlm. 115.

34 Hendra Pramono, "Perlindungan Hukum Lisensi Hak Merek terkenal di dalam Sistem Hukum Indonesia”, Artikel dalam Majalah Hukum Varia Peradilan, Tahun Ke XXII No. 258 Mei 2007, hlm 76.

${ }^{35}$ Syukur Sarto, Op. Cit. hlm. 6.
} 
Pada berbagai pertemuan ilmiah, pihak Dirjen Pengawasan selalu berkilah bahwa rendahnya pengawasan PPNS Kemenakertrans karena jumlah petugas pengawas sangat sedikit dibandingkan dengan jumlah perusahaan yang diawasi. Alasan klasik ini tentulah sulit untuk diterima, meskipun jumlah petugas pengawas sedikit tetapi dengan jumlah yang sedikit petugas, mereka dapat bekerja sungguh-sungguh sehingga dapat menunjukkan prestasi kerja kepada rakyat. Prestasi pengawas dalam pelaksanaan tugasnya, misalnya: 1) telah melaksanakan pengawasan dan penindakan terhadap 1.000 perusahaan yang membayar upah di bawah UMP; dan 2) telah membina 4.000 perusahaan untuk melaksanakan Program Jamsostek dan 50 persen diantaranya menjadi peserta jamsostek.

\section{Kendala dalam Tataran Budaya Hukum (Pemerintah, Pekerja, dan Pengusaha)}

Budaya atau kultur adalah nilai-nilai dan sikap-sikap yang merupakan pengikat sistem akan berhadapan dengan hukum, yang mana hukum dibelenggu oleh kontradiksi-kontradiksi, pada kenyataan sekarang benar adanya. Sistem upah minimum (UMP) sebagai kebijakan pemerintah, telah membelenggu upah pekerja sehingga menjadi tidak layak. Hak atas penghidupan yang layak pada Pasal 27 ayat (2) UUD NRI Tahun 1945 dan upah yang layak pada Pasal 88 ayat (1) UUK, terkesan hanya menjadi tulisan yang tidak dapat dibuktikan kebenarannya dalam kehidupan sehari-hari pekerja.

Akibat dari belum teratasi kendala-kendala yang dihadapi oleh Dewan Pengupahan, maka hingga saat ini upah yang layak untuk dapat hidup sejahtera bagi pekerja masih jauh dari harapan. Cara lain dapat ditempuh, yaitu pengusaha harus berani menawarkan gagasan mensejahterakan pekerja dengan memotong mata-rantai pengeluaran pekerja sehari-hari, seperti: biaya hidup yang tinggi di perkotaan dan biaya transportasi, seperti perusahaan-perusahaan di Jepang mencari lokasi pabriknya kepedesaan.

Perubahan budaya di Jepang menurut Minoru Ito, bahwa kebangkitan kembali industri manufaktur dapat dilihat dari pertumbuhan jumlah pabrik pada tahun-tahun terakhir. Perusahaan sebelum 2006, berusaha mendirikan 
perusahaan dengan kedekatan lokasi dengan perusahaan dan pasar. Setelah 2006 tanggapan bergeser menjadi kedekatan dengan tenaga kerja di pedesaan. Di masa lalu, relokasi perusahaan dilakukan untuk menempatkan diri mereka dalam jaringan bisnis dan kedekatan perusahaan terhadap pasar dan perusahaan lain yang berkaitan. Tetapi baru-baru ini terjadi peningkatan jumlah perusahaan yang memindahkan pabrik mereka ke lokasi yang baru dengan alasan kedekatan dengan tenaga kerja. Hal ini menunjukkan adanya peningkatan kemungkinan bagi perusahaan untuk pindah ke daerah pedesaan yang saat ini belum merasakan manfaat dari pemulihan ekonomi dan jumlah tenaga kerja yang belum banyak terserap. 36

Pola perubahan budaya pada perusahaan-perusahaan Jepang ini, dapat ditiru oleh perusahaan-perusahaan Indonesia. Sehingga keuntungan yang didapatkan, sebagai berikut: 1) terjadi pemeratan kesempatan kerja di pedesaan, 2) kepadatan penduduk di perkotaan dapat diminimalisir, 3) pekerja di pedesaan tidak memikul beban biaya hidup tinggi seperti pekerja di perkotaan, dan 4) kehidupan masyarakat pedesaan menjadi sejahtera.

Kesejahteraan berdasarkan hukum, akan adil secara yuridis empiris, sebab hakekat hukum yang bekerja dalam masyarakat dan untuk keadilan masyarakat banyak. Oleh karena itu, keberlakuannya harus didukung oleh masyarakat dan sesuai dengan nilai-nilai dan cita-cita hidup masyarakat serta memiliki relevansi dengan tradisi hukum masyarakat itu sendiri. ${ }^{37}$

Masyarakat berpikir ke depan, dengan pembangunan nasional dilandasi oleh sistem ekonomi kreatif yang dicanangkan pemerintah. Masalah pengangguran dan kemiskinan akan dapat diminimalisir, jika target ekonomi kreatif tercapai nantinya 2025. Sebab menurut Moh. Mahfud MD, bahwa salah satu problem penegakan hukum adalah masalah pekerja dan pengangguran. Kelompok pengangguran didominasi oleh kelompok umur antar 15-24 tahun mencapai 24 persen, jauh lebih besar dari kelompok umur 25-54 tahun yang mencapai 3,5 persen, dan kelompok umur 55 tahun ke atas yang mencapai 5,4

${ }^{36}$ Minoru Ito, "Measures for Supporting Regional Job Creation in Japan”, Japan Labor Review, Volume 5, Number 1, Winter 2008, hlm. 95.

37 I Nyoman Ngurah Suwarnatha, "Kebijakan Hukum Pemidanaan Anak Dalam Konsep KUHP 2010”, Jurnal Advokasi, No. 1 September 2011, hlm 2. 
persen. Ini berarti bahwa sangat banyak penduduk yang seharunya masih bersekolah (usia 15-24 tahun) terpaksa menjadi penganggur karena tidak mempunyai biaya untuk bersekolah sehingga mereka memilih untuk mencari pekerjaan. ${ }^{38}$ Pekerja adalah salah satu bagian dari masyarakat atau warganegara yang menjadi korban dari lemahnya penegakan hukum.

Kedudukan pekerja pada hakikatnya dapat ditinjau dari dua segi, yaitu dari aspek yuridis dan aspek sosial ekonomis. Pertama, aspek yuridis-sosiologis, pekerja membutuhkan perlindungan hukum dari negara atas kemungkinan adanya tindakan sewenang-wenang dari pengusaha. Berdasarkan ketentuan Pasal 27 UUD NRI Tahun 1945, yaitu setiap warga negara bersamaan kedudukannya dalam hukum dan pemerintahan. Ketentuan ini dijabarkan lebih lanjut dalam Pasal 5 UU No.13 Tahun 2003 Tentang Ketenagakerjaan. Pasal 5, yaitu setiap tenaga kerja memiliki kesempatan yang sama tanpa diskriminasi untuk memperoleh pekerjaan. Pasal 6, yaitu Setiap pekerja/buruh berhak memperoleh perlakuan yang sama tanpa diskriminasi dari pengusaha.

Kedua, secara sosial ekonomis kedudukan buruh adalah tidak bebas. Sebagai orang yang tidak mempunyai bekal hidup lain dari itu, ia terpaksa bekerja pada orang lain. Majikan inilah yang pada dasarnya menentukan syarat-syarat kerja. Mengingat kedudukan pekerja yang lebih rendah daripada majikan maka perlu adanya campur tangan pemerintah untuk memberikan perlindungan hukumnya. ${ }^{39}$ Perlindungan hukum pemerintah dalam bentuk kebijakan sudah cukup banyak, sebagai upaya untuk meningkatkan upah pekerja yang diikuti dengan produktivitas. Namun hingga saat ini, unjuk rasa berlangsung di setiap akhir-akhir tahun menuntuk kenaikan upah. Artinya pekerja tidak menikmati kesejahteraan dan keadilan di bidang pengupahan khususnya dan hak-hak normatif lainnya,. Keadaan ini berbanding terbalik dengan warga negara yang lain, seperti: ASN, pedagang, dan pengusaha. 40

Secara sosiologis, kedudukan buruh dan majikan atau antara pengusaha dengan pekerja berbeda dengan kedudukan antara penjual dan pembeli. Antara

38 Moh. Mahfud MD, Perdebatan Hukum Tata Negara Pasca amandemen Konstitusi, Penerbit Rajawali Pers, Jakarta, 2011, hlm 174.

39 Asri Wijayanti, Hukum Ketenagakerjaan Pasca Reformasi, Penerbit Sinar Grafika, Jakarta, 2009, hlm. 8.

40 Zulkarnain Ibrahim, "Sejarah Hukum Ketenagakerjaan: Studi Terhadap Pasang Surutnya Keadilan Sosial Pekerja”, Artikel dalam Jurnal Simbur Cahaya, Vol. XX, No. 51, Mei 2013, hlm 35-48. 
penjual dengan pembeli sama kedudukannya. Antara keduanya mempunyai

kebebasan yang sama untuk menentukan ada atau tidaknya perjanjian. Namun kedudukan antara pengusaha dengan pekerja adalah tidak sama. Secara yuridis kedudukan buruh adalah bebas, tetapi secara sosial ekonomis kedudukan buruh adalah tidak bebas. Pada hakikatnya, pekerja dengan pengusaha dalam proses produksi, mempunyai kedudukan yang sama atau sejajar berdasarkan perjanjian kerja atau perjanjian kerja bersama.

Untuk keberlakuan hukum, diperlukan penegakan hukum yang konkrit melalui lembaga-lembaga yang kredibel. Lembaga-lembaga yang diberi tugas/fungsi menegakkan hukum pengupahan, pada dasarnya adalah saranasarana Hubungan Industrial yang diatur dalam Pasal 102 dan Pasal 103 UUK. Hubungan industrial dapat dilaksanakan melalui sarana-sarana di atas, pada dasarnya digantungkan pada peran dari: 1) Kemenakertrans/ Disnakertrans); 2) SP/SB; dan 3) Pengusaha (Apindo/Kadin).

\section{Penutup}

Berdasarkan pembahasan di atas, pengaturan dan penegakan hukum pengupahan dalam dalam upaya mewujudkan kesejahteraan sosial pekerja; telah dijamin oleh UUD NRI Tahun 1945 (Pasal 27 ayat (2) dan Pasal 28 ). Namun UUD NRI Tahun 1945: 1) telah dilemahkan oleh UUK dengan praktik labour market system dan PHK sepihak oleh pengusaha; 2) UUK memberi peluang kepada pengusaha untuk mengabaikan kewajibannya menghormati hak asasi SP/SB untuk berserikat dan berkumpul di lingkungan perusahaan tersebut; dan 3) lemahnya Pengawasan Kemenakertrans tidak terjebak pada alasan klasik dengan alasan sedikit PPNS dibandingkan dengan jumlah perusahaan yang diawasi, tanpa menunjukkan prestasi kerja yang maksimal. Pengusaha harus mengangkat kearifan lokal menjadi kearifan perusahaan, tidak terjebak pada budaya kapitalisme dan hukum mengatakan begitu.

Peneliti menyarankan: pertama, praktik pelemahan terhadap hak-hak pekerja dalam UUD NRI Tahun 1945 oleh pengusaha dengan memanfaatkan celah dalam UUK serta PPNS Kemenakertrans yang tidak profesional 
melaksanakan tugas. Umpan balik, Kewajiban pekerja harus didukung dengan peningkatan kualitas atau produktivitas pekerja sebagai wujud dari akumulasi pendidikan, pelatihan dan pengalaman kerjanya. Kedua, sistem pengawasan oleh PPNS Kemenakertrans, harus ditingkatkan mutu berdasarkan kewajiban yang diamanatkan oleh perundang-undangan ketenagakerjaan dan UU. No. 5 Tahun 2014 Tentang Aparatus Sipil Negara. Ketiga, sarana-sarana Hubungan Industrial yang diatur dalam UUK, harus berfungsi dengan benar dan baik didukungan Kemenakertrans dan institusi lain.

\section{Daftar Pustaka}

Agusmidah, Dilematika Hukum Ketenagakerjaan, Tinjauan Politik Hukum, PT. Sofmedia, Medan, 2011.

Bastos, Paulo and Joana Silva, "The Wage and Unemployment Impacts of Trade Adjustment" Dalam: David Greenaway cs, Globalisation and Labour Market Adjustment, Palgrave Macmillan, New York, 2008.

Husni, Lalu, Pengantar Hukum Ketenagakerjaan Indonesia, Edisi Revisi, PT. RajaGrafindo Persada, Jakarta, 2005.

Mahfud MD, Moh., Membangun Politik Hukum, Menegakkan Konstitusi, Jakarta: PT RajaGrafindo, Jakarta, 2011.

Perdebatan Hukum Tata Negara Pascaamandemen Konstitusi, Jakarta: Rajawali Pers, Jakarta, 2011.

Makoba, Johnson W., Globalization and Marginalization of Labor: Focus on SubSaharan Africa; Dalam: Berch Berberoglu, Globalization In The 21 st Century: Labor, Capitral, and State on a World Scale, Palgrave Macmillan, New York, 2010.

Mujahidin, Ahmad, Peradilan Satu Atap Di Indonesia, Refika Aditama, Bandung, 2007.

Rato, Dominikus, Filsafat Hukum., Mencari, Menemukan, dan Memahami Hukum, LaksBang Justitia, Surabaya, 2011.

Rahardjo, Satjipto, Negara Hukum yang Membahagiakan Rakyatnya, Genta Publishing, Yokyakarta, 2009

Rasjidi, H. Lili, Pembangunan Sistem Hukum Dalam rangka Pembinaan Hukum Nasional; Dalam: B. Arief Sidharta, Butir-Butir Pemikiran Dalam Hukum, Memperingati 70 Tahun Prof. Dr. B. Arief Sifharta, S.H., Bandung: Refika Aditama, Bandung, 2008. 
Surahman, R.M., Ombudsman Indonesia, Pelayanan Publik dan Asas-asas Hukum bagi Pemerintahan yang Baik; Dalam: Elly Erawaty dkk, Beberapa Pemikiran Tentang Pembangunan Sistem Hukum Nasional Indonesia, Bandung: Citra Aditya Bakti, Bandung, 2011.

Wijayanti, Asri, Hukum Ketenagakerjaan Pasca Reformasi, Sinar Grafika, Jakarta, 2009.

\section{Jurnal dan Makalah:}

Aviliani, "Biaya Tenaga Kerja di Indonesia", Makalah pada Forum Konsolidasi Dewan Pengupahan se Indonesia, Jakarta, tanggal 3-5 September 2013.

Batubara, Cosmas, "Menyegarkan Kembali UMP dan Upah yang Adil", Makalah pada Seminar Ketenagakerjaan, Hotel Ciputra Jakarta, 15-16 Maret 2012.

Hermintasdi, Tri, Efektivitas Pelaksanaan Hukum di Bidang Hukum Perburuhan Berdasarkan UU. No. 13 Tahun 2003 Tentang Ketenagakerjaan, Majalah Hukum Varia Peradilan, No. 281, April 2009.

Ibrahim, Zulkarnain, Sejarah Hukum Ketenagakerjaan: Studi Terhadap Pasang Surutnya Keadilan Sosial Pekerja, Jurnal Simbur Cahaya, Vol. XX, No. 51, Mei 2013.

Ito, Minoru, Measures for Supporting Regional Job Creation in Japan, Japan Labor Review, Volume 5, Number 1, Winter 2008.

Kikawa, Takeo, 2008, Community Based Renaissance and Job Creation in Japan, Hitotsubashi University, Japan Labor Review Vol. 5, no. 1, Winter, 2008.

Ono, Yoshihiko, “Upah Minimum Jepang”, disampaikan pada Forum Konsolidasi Dewan Pengupahan se Indonesia, Jakarta, tanggal 4 September 2013

Pramono, Hendra, Perlindungan Hukum Lisensi Hak Merek terkenal di dalam Sistem Hukum Indonesia, Majalah Hukum Varia Peradilan, Tahun Ke XXII No. 258 Mei 2007.

Sarto, Syukur, "Upah untuk Menjaga Produktivitas Kerja”, Makalah pada Seminar Kemenakertrans, Hotel Ciputra, Jakarta, tanggal 15-16 Maret 2012.

Suwarnatha, I Nyoman Ngurah, Kebijakan Hukum Pemidanaan Anak Dalam Konsep KUHP 2010, Jurnal Advokasi, No. 1 September 2011.

Yamagami, Toshihiko, Utilization of labor resources in Japan and the United States, Monthly Labor Review April 2002.

Wiryawan, I Wayan Gde, " Efektifitas Upah Minimum dalam Sistem Penetapan Upah di Indonesia", Makalah pada Forum Konsolidasi Dewan Pengupahan se Indonesia, Jakarta, tanggal 3-5 September 2013.

\section{Surat Kabar:}

Kompas, 30 April 2008

Sumatera Ekspres, 11 Februari 2011 